Górska, A. 2009. "Kronika i komentarze: Ukraina - Problemy budżetowe Ukrainy?", Nowa Europa Wschodnia, 2: 19 (in Polish)

Łysek, W. 2012. "Polityka zagraniczna wobec Ukrainy”. In : Gtówne kierunki polityki zagranicznej rzadu Donalda Tuska w latach 2007-2011, edited by P. Musiałek, Kraków: 261-78. (in Polish)

Sus, M. 2014. "Niemcy i Polska wobec konfliktu ukraińsko-rosyjskiego w drugiej połowie 2014 r.", Biuletyn Niemiecki, 54: 2-7 (in Polish)

"Ukrainians Again Ask Forgiveness for Volyn". 2016. The Ukrainian Truth. June, 03. URL: http://www.istpravda.com.ua/short/2016/06/3/149102/. (in Ukrainian)
Poles Ask the Ukrainians for Forgiveness for Their Historical Wrongs. 2016. The Ukrainian Truth. July, $04 . \quad$ URL: http://www.istpravda.com.ua/short/2016/07/4/149125/. (in Ukrainian)

Sheptytskyy, A. 2016. "Non-response", Zaxid.net., June, 15 https://zaxid.net/zvernennya_bez_vidpovidi_n13950 03 (in Ukrainian)

Boichuk, O., i I. Hryniuk. 2017b. "Stosunki polsko-ukraiński po rewolucji godności: wymiar społeczny". In : Sociosphere in the modern world: current issues and aspects of humanitarian knowledge Interuniversity Round table. Lutsk: Lutsk NTU: 32-33 (in Polish)

DOI: $10.26565 / 2220-8089-2020-37-15$

УДК 321.01

\author{
Khrystyna Martsikhiv \\ Assistant professor, \\ Ph.D. in pedagogical sciences, \\ National University \\ "Lviv Polytechnic", \\ street S. Bandery 12, Lviv, 79013, Ukraine, \\ khrystyna.hrytsko@gmail.com, \\ https://orcid.org/0000-0003-4637-6604 \\ Lesya Shepelyak \\ undergraduate student, \\ National University \\ "Lviv Polytechnic", \\ street S. Bandery 12, Lviv, 79013, Ukraine, \\ spepelyaklesya0404@gmail.com, \\ https://orcid.org/0000-0002-6142-2069
}

\title{
GEOPOLITICAL GOALS AND GEOSTRATEGY OF UKRAINE
}

The issues related to the definition of the essence of the concept of "geopolitics" are considered, the geostrategy of Ukraine is studied, and the factors influencing its formation, the main geopolitical goals of Ukraine are characterized. Geostrategy as a practical component of geopolitics is analyzed in detail. The peculiarities of the modern geostrategy of Ukraine are revealed, the main goals used by the states to achieve certain results are given.

The main goals and principles of forming the geostrategy of Ukraine are studied and determined, which is an extremely important topic, because in modern conditions a new geopolitical world is emerging, and Ukraine is trying to establish itself in the international arena as an active geopolitical player. The main attention is paid to one of the most important factors that play a significant role in the development of the geopolitical code of any country - the geopolitical position of its territory, the state of the treaty base and relations with other countries, common borders, geopolitical situation in the region and the world. It is noted that the geopolitical position is one of the main determinants that determine the specifics of the geostrategy of any state in geospace. Penetration into the wider world begins with attempts to understand it, establish contacts with it and enter into a multifaceted dialogue. It is emphasized that only then can we find those forms of presentations of our own identity and our own interests in which the world will be able to understand ourselves. Ukraine must realize itself in the geopolitical context and in the context of the development of world civilization. It turns out that the definition of geopolitical interests of Ukraine requires consideration of a complex system 
Вісник ХНУ імені В. Н. Каразіна, серія «Питання політології», вип. 37, 2020

of interests of different countries, the distribution of forces - economic, political, military, spiritual - in each of the regions of the world.

Key words: Ukraine, geostrategy, geopolitics, geopolitical goals, geopolitical code, geopolitical situation, geospace, international system.

\section{Марціхів Христина Романівна \\ викладач, к.пед.н., \\ Національний університет \\ «Львівська політехніка», \\ вул. С. Бандери 12, м. Львів,79013, \\ khrystyna.hrytsko@gmail.com, \\ https://orcid.org/0000-0003-4637-6604}

\section{Шепеляк Леся Тарасівна}

Студентка бакалаврата,

Національний університет

«Львівська політехніка»,

вул. С. Бандери 12, м. Львів,79013,

spepelyaklesya0404@gmail.com,

https://orcid.org/0000-0002-6142-2069

\section{ГЕОПОЛІТИЧНІ ЦІЛІ ТА ГЕОСТРАТЕГІЯ УКРАЇНИ}

Розглянуто питання, пов'язані з визначенням сутності поняття «геополітика», також досліджено, щсо таке геостратегія України, та чинники, щзо впливають на ї̈ становлення, охарактеризовано основні геополітичні иілі України. Детально проаналізовано геостратегію як практичну складову геополітики. Розкрито особливості сучасної геостратегії України, подано основні иілі, які використовуються державами для досягнення певних результатів.

Досліджено та визначено основні иілі та принципи формування геостратегії Украӥни, щзо є надзвичайно актуальною темою, адже в сучасних умовах відбувається становлення нового геополітичного світу, і Украйна намагається заявити про себе на міжнародній арені як активний геополітичний гравець. Приділено основну увагу одному з найважливіших чинників, що відіграють значну роль у розробиі геополітичного коду будь-якої країни - геополітичному положенню ї̈ території, стану договірної бази і відносинам з іншими країнами, наявності спільних кордонів, геополітичній ситуація в регіоні та у світі. При иьому зазначено, що геополітичне положення, $\epsilon$ однією з головних детермінант, щи визначають специфіку геостратегії будь-якої держави в геопросторі. Проникнення у широкий світ починається зі спроб зрозуміти його, налагодити з ним контакти $i$ вступити в багатоплановий діалог. Підкреслено, ще тільки тоді можна знайти ті форми презентацій власної ідентичності $i$ власних інтересів, в яких світ зможе зрозуміти і нас самих. Україна має усвідомити себе в геополітичному контексті і в контексті розвитку світової циивілізації. Доводиться, що визначення геополітичних інтересів України потребує врахування складної системи інтересів різних краӥн, розкладу сил - економічних, політичних, військових, духовних - у кожному з регіонів світу.

Ключові слова: Украӥна, геостратегія, геополітика, геополітичні иілі, геополітичний код, геополітична ситуачія, геопростір, міжнародна система. 
Марцихив Кристина Романовна

преподаватель, к.пед.н.,

Национальный университет «Львовская политехника»,

ул. С. Бандеры 12 м. Львов, 79013, khrystyna.hrytsko@gmail.com https://orcid.org/0000-0003-4637-6604

\author{
Шепеляк Леся Тарасовна \\ Студентка бакалаврата, \\ Национальный университет \\ «Львовская политехника», \\ ул. С. Бандеры 12 м. Львов, 79013, \\ spepelyaklesya0404@gmail.com, \\ https://orcid.org/0000-0002-6142-2069
}

\title{
ГЕОПОЛИТИЧЕСКИЕ ЦЕЛИ И ГЕОСТРАТЕГИЯ УКРАИНЫ
}

\begin{abstract}
Рассмотрены вопросы, связанные с определением сущности понятия «геополитика», также исследовано, что такое геостратегия Украины, и факторы, влияюшие на ее становление, охарактеризованы основные геополитические иели Украины. Детально проанализированы геостратегию как практическую составляющую геополитики. Раскрыты особенности современной геостратегии Украины, представлены основные иеели, которые используются государствами для достижения определенных результатов.

Исследованы и определены основные иели и принципь формирования геостратегии Украины, что является чрезвычайно актуальной темой, ведь в современных условиях происходит становление нового геополитического мира, и Украина пытается заявить о себе на международной арене как активный геополитический игрок. Уделено основное внимание одному из важнейших факторов, играющих значительную роль в разработке геополитического кода любой страны - геополитическому положению ее территории, состояния договорной базы и отношениям с другими странами, наличии общих грании, геополитической ситуация в регионе и в мире. При этом отмечено, что геополитическое положение, является одной из главных детерминант, определяющих специфику геостратегии любого государства в геопространстве. Проникновение в широкий мир начинается $c$ попыток понять его, наладить с ним контакты и вступить в многоплановый диалог. Подчеркнуто, что только тогда можно найти те формы презентации собственной идентичности и собственных интересов, в которых мир сможет понять и нас самих. Украина должна осознать себя в геополитическом контексте и в контексте развития мировой ииивилизачии. Доказывается, что определение геополитических интересов Украинь требует учета сложной системы интересов различных стран, расклад сил - экономических, политических, военных, духовных - в каждом из регионов мира.
\end{abstract}

Ключевые слова: Украина, геостратегия, геополитика, геополитические иели, геополитический код, геополитическая ситуация, геопространство, международная система.

Research and definition of the main goals and principles of forming the geostrategy of Ukraine is an extremely relevant topic, because in modern conditions, there is a new geopolitical World and Ukraine is trying to establish itself in the international arena as an active geopolitical player. The geopolitical position of its territory, the state of the treaty base and relations with other countries, common borders, geopolitical situation in the region and the world are the most important factors that play a significant role in developing the geopolitical code of any country. In this case, the geopolitical situation, in our opinion, is one of the main determinants that determine the specifics of the geostrategy of any state in geospace.

From the research of many scholars, the conlusion is that Ukraine has many advantages over other countries in terms of its geopolitical position and potential. Its main features and priorities of geostrategy of Ukraine are well analyzed in the works of such researchers as OI Shabliy, M. Palamarchuk and O. Palamarchuk, who developed the theoretical and methodological foundations of the study of the 
geopolitical situation of the state and identified the main features of geopolitical location of Ukraine at different spatial levels. At the present stage, we can identify a number of geopolitical concepts that differently interpret the geopolitical position of Ukraine and determine the vectors of its geostrategy, due to its features. Some authors are trying to prove that integration into the Eurasian space is a higher priority for Ukraine, while others are trying to prove integration into the European space. In particular, the Russian geopolitical O. Dugin in his works pays considerable attention to the geopolitical position of Ukraine. $\mathrm{He}$ considers Ukraine as a state hostile to Russia and admits the possibility of losing its independence (Багров 2004:22) . Well-known American geopolitical Z. Brzezinski believes that Ukraine is one of the five geopolitical axes on the political map of Eurasia and has great potential to become an active regional geopolitical player.

The purpose of this article is to examine geostrategy in detail as a practical component of geopolitics. The peculiarities of the modern geostrategy of Ukraine are revealed, as well as the main goals used by the states to achieve certain results are investigated. The goal will be achieved by implementing the following tasks: to analyze what geopolitics is at the present stage; what is the geostrategy of Ukraine; and provide specific goals and principles of geostrategy in the country.

In order to clearly understand the concept and essence of these rather difficult terms geopolitics and geostrategy it is important to define them. The term «geopolitic» consists of two Greek words: geo means land, politicos means everything related to place: state, citizen, etc. Traditionally, geopolitics is considered as the science of the influence of the geographical states' space on their political goals and interests. In modern research, geopolitics is interpreted much more broadly as the science of the relationship and interaction of geographical space and politics. Accordingly, geopolitics must study, on the one hand, the properties of space, which affect certain political actions, their nature and resonance, on the other analyzes the effect of politics on space, its transformation due to the will and goals of people and their communities. This understanding of geopolitics is the most productive (Паламарчук 2000: 680). Scholars see geopolitics as a field of knowledge that studies a set of economic, geographical, demographic, historical, political and other factors that interact with each other and affect the strategic potential of the state. This is how domestic and Russian scientists V. Dergachev, E. Pozdnyakov, K. Hajiyev. V. Tikhonravov, and others interpret geopolitics.

Geostrategy is a synthesis of geopolitically grounded strategic goals, principles and directions of the state's foreign policy. It is classified by scale (global, interregional, regional and national) and by spatial environments (land, sea, air and space). It depends on the understanding of the authorities and the public of the country's place in the world, its geopolitical position, national interests and priorities, the geographical distribution of threats to national security coming from abroad. State geostrategy is also determined by the historically formed for a long time the nature of friendly, neutral, hostile relations with other states (Кудряченко, Рудич, Храмов 2004: 22).

Defining the main principles and priorities the formation of Ukrainian geostrategy provides a reasonable basis to understand the features of the current geopolitical situation in Ukraine, as well as its geopolitical identification. Therefore, the purpose of our study is to determine the main geopolitical goals of Ukraine to achieve certain results. Penetration into the wider world begins with attempts to understand it, establish contacts and enter into a multifaceted dialogue. Only then can we find those forms of presentations of our own identity and interests in which the world will be able to understand ourselves. Ukraine must realize itself in the geopolitical context and in the context of the development of world civilization. Such an awareness is inseparable from how the world community views Ukraine and how it sees its place in the world. Determining the geopolitical interests of Ukraine requires taking into account the complex system of interests of different countries, the distribution of economic, political, military, and spiritual forces in each regions of the world. This is especially true of Ukraine's closest neighbors and forces of global importance that seek to pursue their own interests in Ukraine or are of particular interest to it (Черник 2017:19).

Today, Ukraine is on the way of finding a proper place in the international system. Therefore, geopolitical studies of Ukraine's relations with the states of Central and Eastern Europe are of special importance, as a united Europe is gradually being transformed into one of the world's important centers of power. The turn of the XX-XXI centuries marked by rapid geopolitical changes: the countries of Central and Eastern Europe strongly declared political 
self-determination, Germany reunited, the military-political alliance of the Warsaw Pact and then the USSR collapsed, the Cold War ended, the world ceased to be bipolar. Against the background of these fateful changes on the continent, Ukraine has gained its own independence, which raises the issue of determining the role and place of Ukraine in the world community (Бжезінський 1999: 256).

Thus, during the last decade of the twentieth century there were powerful changes in the alignment of world powers. In fact, for the first time, a non-European state became the only world power: after the collapse of the Soviet Union, the United States quickly rose to prominence as a powerful leader and gradually embodied into a single and truly paramount global power. However, this idea of the model of world order is not entirely true and is somewhat simplistic. The European Union, as well as Russia and the leading countries of the East Asian region, also seek to play the role of poles of both political and economic influence (Дугин 1997: 608). This allows Ukraine to effectively search for its own place and development strategy in the new system of geopolitical coordinates.

Ukraine is located in the center of Europe at the intersection of political, economic, environmental and other interests of the states' region. Thanks to the implementation of a balanced foreign policy, our country opens itself to the world, becomes a full-fledged subject of the European and world political process. However, compared to other countries, Ukraine still lacks a clear strategy for progress, and its potential needs to be used more effectively. Ukraine as a political unit has been represented in international political relations since the national liberation struggle of 1917 1920. Thus, the UPR and the Ukrainian state had all the hallmarks of international legal subjectivity, which testifies to their official recognition and participation in international treaties. The UPR, in particular, legally and de facto recognized 19 states, mostly Western states.

In the interwar period, the Ukrainian question was actively discussed in the League of Nations, and the USSR, for all the real fictitiousness of its state status, in the early 1920s also had some signs of a subject of international legal relations, which manifested itself in the signing in 1921 treaties with Poland, Lithuania, Estonia and Latvia, the signing of the Treaty of Friendship and Brotherhood with Turkey (1922) and the Interim Treaty with Czechoslovakia (1922).
From 1923 to 1944, the USSR did not actually act as a subject of international legal relations (Гальчинський 2002: 56).

Since 1944, in preparation for the establishment of the United Nations, the Ukrainian SSR has been given greater powers in the field of foreign relations and the People's Commissariat (later the Ministry of Foreign Affairs) has been established. Since 1945, the USSR has been a founding member of the United Nations and a member of most international bodies and organizations operating under the auspices of the United Nations. In 1948-1949, the USSR was elected a member of the UN Security Council. Despite the ambiguity of the position and status of the USSR, its membership in the UN has become a positive factor in the international legal establishment of Ukraine in later times.

In the postwar period, the USSR also participated in the signing of agreements on its western borders with Poland, Romania, Czechoslovakia, and acceded to 60 international agreements and conventions. Given the formal statehood of the USSR, during the Second World War and the postwar period, the international activities of independent emigrant political structures continued. In 1944, the Ukrainian State Liberation Council was established by Ukrainian state forces in opposition to the Soviet regime as the supreme body of the Ukrainian people in its revolutionary struggle (Карпенко 2004: 81). The political platform of the UHVR stated that it seeks peaceful cooperation with all of Ukraine's neighbors on the principle of mutual recognition of the right to their own states in the ethnographic lands of each nation. Ukrainian state forces failed to create a single center of foreign policy outside Ukraine, which significantly weakened the effectiveness of their foreign policy actions.

True international recognition and establishment of Ukraine on the political map of the world began after the declaration of independence on August 24, 1991. The Chronicle of official recognition of Ukraine partially outlined the range of international political mutual interests in relation to foreign countries. Thus, Ukraine was first recognized by some Central and Eastern European countries (Poland-December 2, 1991, Hungary - December 3, Lithuania and Latvia - December 4; Russia, Croatia, Bulgaria - December 5), as well as countries with an influential Ukrainian diaspora (Canada - December 2 and Argentina - December 5). This once again convincingly proved the importance of the ethnic factor and 
the role of the neighboring geopolitical location. Of the neighboring states, Romania was the latest to recognize Ukraine (January 8, 1992). Of the Nordic and Western European countries, Ukraine was first recognized by Sweden, and of the G7 countries (after Canada) by the United States (December 25, 1991). As of July 1997, Ukraine was recognized by 145 states, 128 of which had formal relations. More than 60 embassies and consulates have been opened in Kyiv, half of them European countries (Ключко 2005: 191).

Today, Ukraine occupies a central-eastern position on the European subcontinent and directly borders seven countries: Russia, Belarus, Poland, Slovakia, Hungary, Romania, and Moldova. A large number of first-order neighbors is a positive aspect of Ukrain's political and geographical position. As a result, it has many options for foreign relations, as well as opportunities to enter the outside world.

The geopolitical situation and historical conditions of Ukraine's development have determined for the future its axis of geostrategy, which have a certain influence on its state selfaffirmation and priorities of economic, political and cultural development. Such geopolitical axes for Ukraine are the following:

- Eurasian, or Eastern, with a center of attraction in Russia;

- Euro-Atlantic, or Western, with political centers of structures - NATO and the EU;

- North, which is focused on cooperation with the countries of the «Baltic Arc»;

- Black Sea, or southern, which provides for deepening cooperation with the countries of the Black Sea basin, the Middle East (Кудряченко, Рудич, Храмов 2004: 296).

Ukraine's neighbors differ significantly in size, level of socio-economic development, political system and landmarks. According to the grouping of European countries by area, it is divided into separate groups of the largest states, very large states, large, medium, small, very small and smallest. Russia is one of the largest countries, Poland, Romania and Belarus are also considered among the largest, Hungary is one of the medium-sized countries, and Moldova and Slovakia are among the smallest.

Active cooperation with those countries that see Ukraine as a reliable equal partner, free from great-power and hegemonic ambitions. Developing the principles of the national security strategy in accordance with national interests, basic geopolitical and foreign policy priorities is one of the most important tasks for Ukraine today. In our opinion, the unambiguous solution to the geopolitical dilemma is joining the European civilization space as a full-fledged subject of Euro-Atlantic geopolitics is, at the present stage, one of the most priority directions for the Ukrainian state. It should be noted that the main basic national interest, geopolitical priority and strategic task of Ukraine's foreign policy is its survival and development as an independent sovereign state of the modern world while preserving its national values, protection of economic and political sovereignty, its own socio-cultural identity. This interest is now becoming widely accepted both among the ruling elite and in the mass consciousness. Its implementation is the main prerequisite for ensuring the well-being, security, social and cultural development of all citizens of Ukraine (Медісон, Шахов 2003:97). After all, the strengthening of the state sovereignty of Ukraine in the foreign policy plane means its assertion in the world civilization space as a full-fledged and active subject of geopolitics.

According to the level of socio-economic development, all neighboring states belong to countries with economies in transition, which are undergoing complex processes of sociopolitical transformation. Poland and Hungary have achieved the greatest success on this path, Slovakia and Romania are doing somewhat worse, and Russia, Belarus and Moldova have the most problems. Ukraine belongs to the third group in all economic respects (Паламарчук, Паламарчук 1994:3-9).

Ukraine has almost half of all world resources of fertile chernozem soils, powerful industrial and scientific-technical potential, well-developed infrastructure and at the same time feels the urgent need for economic restructuring, weak export opportunities, loss of traditional markets, and rupture of foreign economic ties.

In the first years of independence, Ukraine demonstratively rejected the Eurasian geopolitical axis. However, with the awareness of Ukraine's remoteness (in terms of economic and political level of development) from Western countries, more and more views began to turn to the East. The Eurasian axis is important for Ukraine, first of all, from the economic point of view, because the eastern market is a supplier of energy and raw materials to Ukraine and a market for Ukrainian products (because in the western market Ukraine is not able to compete with high quality products). It is obvious that the identification of Ukraine as a sphere of «vital interests» of Russia equally identifies Russia as a sphere of «vital interests» of Ukraine itself. 
With the independence, the Euro-Atlantic axis became dominant in Ukraine's foreign policy orientations. The formation of Ukraine as an independent state required a clear idea of the self-worth of its own cultural identity, the invention of its own path, its own paradigm of social development. The factor of financial support from Western structures also played an important role.

The western direction of Ukraine's foreign policy was also conditioned by the natural aspirations of the Ukrainian people to a higher standard of living for the population of the state and to establish democratic values in Ukraine. An example of this could be Western countries. Ukraine's western neighbors (Poland, Romania, Slovakia, and Hungary) are members of NATO and the EU, which raises the issue of Ukraine's relations with these alliances. Poland, Hungary and Slovakia, along with the Czech Republic, are members of the Vise grad Group, a regional political union. Having chosen the path of integration into the political structures of the West, Ukraine gradually became a full member of the Organization for Security and Cooperation in Europe (OSCE), the InterParliamentary Union, the Central European Initiative (CEI), became a member of the Council of Europe and signed the EU Partnership and Cooperation Agreement (Василенко 2000:206).

Charter on a special partnership with NATO. However, when integrating with the West, it is necessary to take into account the fact that for the West the strategy of modernization of Ukraine is, first, the expansion of its own geopolitical and geo-economics space in the Eastern European region. Therefore, it is important for Ukraine to prevent Ukraine from becoming a buffer zone between the West and the East, to become a subject (not an object) of geopolitics, as it is obvious that these civilizations are trying to drag Ukraine into the sphere of their interests.

The Northern Axis of foreign policy is strategically important for Ukraine. Cooperation with the Baltic States and Poland strengthens ties with the Nordic countries. The Baltic Arc states are the best example of rapid economic growth and political transformation for Ukraine. Poland is a profitable partner for lobbying Ukrainian interests in the Western structures of which it is a member. Poland also supports Ukraine's accession to these structures, but Ukraine has yet to implement a number of reforms in order to be able to talk about joining the EU or NATO. The northern geopolitical axis is a kind of reflection of the Baltic-Black
Sea Union of S. Rudnytsky. However, there is no Belarus in the current «union», which for obvious reasons does not want to be its structural element. The role of Belarus is played by Poland, which is a more important and reliable ally. The development of relations with the countries of the Baltic Arc contributes to the development of Ukraine and the strengthening of its role in the international arena.

The Black Sea Axis is special for Ukrainian geopolitics. Nature has ordered that all natural routes from Ukraine lead to the Black Sea. The Black Sea is an important natural border of Ukraine. It is through cooperation with the countries of the Black Sea region that our state can act as an independent subject of geopolitics, without being dependent on the policies of Russia and the West. Cooperation with the countries of the Middle East is intensifying through this region, as Ukraine is a Mediterranean country through the Bosporus and the Dardanelles. Through the Black Sea, Ukraine is actively developing cooperation with the countries of the Caucasus and Central Asia, bypassing Russia. In regional cooperation, Ukraine is developing both bilateral and multilateral ties in the political and economic spheres. Such formations as the Black Sea Economic Union, the Baltic-Black Sea Axis, GUAM, etc. play a significant role in the political and economic development of the state (Яценко, Стафійчук, Брайчевський 2007: 255).

Thus, Ukraine's geostrategy must be based on clearly defined geopolitical priorities and a well-defined circle of its strategic partners. According to Mykhalchenko, Ukraine should be identified as a priority in one of three possible geostrategic directions: either choose the path to European cooperation, or provide guarantees of independent development from both the West and Russia, or choose a position of dynamic balance between the East and An event that is supported by the international community and which, in his opinion, is the most promising.

S. Pyrozhkov defines the essence of modern Ukrainian geostrategy somewhat differently, believing that the following tasks will be relevant for Ukraine in the 21st century:

In the short term it is the prevention of isolation in the main strategic areas (USA, Europe, Asia); in the medium term it is promoting the formation of regional security systems and cooperation in neighboring regions; integration into international economic and political structures; participation in the settlement of international conflicts, the fight against international terrorism and crime, in 
solving environmental, energy, resource, information and other global problems. In the long run it is the preservation and strengthening of the positions of our state in world politics; active participation in the formation of a democratic global system of international order.

Thus, as strategic directions, the author defines that relations with the USA, Europe and Asia, and realization of tasks of multilevel policy of Ukraines' multi-vector will depend on how much our state independently - politically, economically and culturally - will be able to establish itself in new geopolitical realities.

Today it is impossible to consider international relations as a holistic, orderly system of relations between the subjects of international life without Ukraine, which occupies an equal place among other states. In the process of Ukraine's formation as a subject of international relations, our state has been recognized by the modern world, Ukraine has taxed and continues to establish direct relations with other states and international organizations, joins international agreements, has the opportunity based on its own geopolitical position and national interests in the international arena. , to resolve issues of war and peace. The content of Ukraine's foreign policy determines the activities to ensure the national interests of the state, especially guaranteeing its national security, which is manifested in the pursuit of European and EuroAtlantic integration of Ukraine, the development of bilateral interstate relations, expanding participation in regional cooperation and more.

Conclusions. Thus, the issue of foreign policy planning of Ukraine becomes especially relevant, given its important geopolitical and geostrategic position in the regional and global international system. These circumstances require the state leadership to be active in foreign policy, in order to develop Ukraine's image as a reliable, stable and predictable partner that will contribute to economic prosperity and security not only of our country but also the region as a whole.

Unfortunately, today, it is necessary to state the absence of clearly defined, well thought out, legally legitimized priorities in foreign policy, which does not allow concentrating diplomatic and economic activities in those regions that are and may be strategically important for Ukraine. Among them are, first of all, the regions of Central and Eastern Europe, the Black Sea Basin and the Balkans, as well as the countries of Western Europe, the countries of the Black Sea Basin, the Caucasus and, despite all reservations, Russia. It is also necessary to point out the importance for Ukraine of relations with the countries of the Middle East and Central Asia, as well as strategic partnership with the United States.

Prospects for further research. A wide range of goals and principles stands in the way of Ukraine's geostrategy. Unfortunately, today, it is necessary to state the absence of clearly defined, well thought out, legally legitimized priorities in foreign policy, which does not allow concentrating diplomatic and economic activities in those regions that are and may be strategically important for Ukraine.

\section{REFERENCES}

Багров, М.В. 2002. Региональная геополітика устойчевого развития. Київ.: Либідь.

Паламарчук, М. М. 2000. Сочіальноекономічна географія України: підручник. Київ.: Вид-во Либідь.

Кудряченко, А., Рудич, Ф., Храмов, В. 2004. Геополитика.

URL:

http://elibrary.ivinas.gov.ua/3/1/\%D0\%93\%D0\%B5 $\% \mathrm{D} 0 \% \mathrm{BE} \% \mathrm{D} 0 \% \mathrm{BF} \% \mathrm{D} 0 \% \mathrm{BE} \% \mathrm{D} 0 \% \mathrm{BBi} \% \mathrm{D} 1 \% 82$ $\% \mathrm{D} 0 \% \mathrm{~B} 8 \% \mathrm{D} 0 \% \mathrm{BA} \% \mathrm{D} 0 \% \mathrm{~B} 0 . \% \mathrm{D} 0 \% 9 \mathrm{Fi} \% \mathrm{D} 0 \% \mathrm{~B} 4$ $\% \mathrm{D} 1 \% 80 \% \mathrm{D} 1 \% 83 \% \mathrm{D} 1 \% 87 \% \mathrm{D} 0 \% \mathrm{BD} \% \mathrm{D} 0 \% \mathrm{~B} 8 \%$ D0\%BA.pdf

Черник, П. 2017. Геополітичне положення України в Центрально-Східній Європі. Львів.: Львівський національний університет імені I. Франка: дис... канд. політ. наук : 23.00.04.

Бжезінський, 3. 1999. Американське панування та його геостратегічні імперативи. Міжнародні відносини. Івано-Франківськ.: Лілея

Дугін, А.Г. 1997. Основи геополітики. Геополітичне майбутне Росії. Москва.: Арктогея-центр.

Гальчинський, А.С. 2002. Україна - на перехресті геополітичних інтересів. Київ.: Знання України.

Карпенко, М.М. 2004. "Свропейський вектор y розвитку геостратегії Украӥни”. Харків. Наукові праці. Вип. 56, том 147: 69-120.

Ключко, Д. 2005. Геостратегічна дилема України: теоретико-методологічний аналіз та інституиійні рішення. Харків.: Харківський національний університет імені В.Н.Каразіна: Дис... канд. політ. наук: 23.00.02 URL: http://www.disslib.org/heostratehichna-dylemaukrayiny-teoretyko-metodolohichnyi-analiz-tainstytutsionalni2.html

Медісон, В., Шахов, В. 2003. Сучасна українська геополітика. Підручник для університетів. Київ.: Либідь.

Паламарчук, М., Паламарчук О. 1994. "Геополітичне становище України (сутність та основні ознаки)". Херсон.: Український географічний журнал 1: 3-9. 
Василенко, С. Д. 2000. Україна: Геополітичні виміри в загальноєвропейському прочесі. Одеса.: ODMA.

Яценко, Б.П., Стафійчук, В.І., Брайчевський, Ю.С. 2007. Політична географія та геополітика. Київ.: Либідь.

\section{REFERENCES}

Bagrov, M.V. 2002. Regional geopolitics of sustainable development. Kyiv .: Lybid' (in Russian)

Palamarchuk, M.M. 2000. Socio-economic geography of Ukraine. Textbook. Kyiv: Lybid (in Ukrainian).

Kudryachenko, A., Rudich, F., Khramov V. Geopolitics. URL: http://elibrary.ivinas.gov.ua/3/1/\%D0\%93\%D0\%B5 $\% \mathrm{D} 0 \% \mathrm{BE} \% \mathrm{D} 0 \% \mathrm{BF} \% \mathrm{D} 0 \% \mathrm{BE} \% \mathrm{D} 0 \% \mathrm{BBi} \% \mathrm{D} 1 \% 82$ $\% \mathrm{D} 0 \% \mathrm{~B} 8 \% \mathrm{D} 0 \% \mathrm{BA} \% \mathrm{D} 0 \% \mathrm{~B} 0 . \% \mathrm{D} 0 \% 9 \mathrm{Fi} \% \mathrm{D} 0 \% \mathrm{~B} 4$ $\% \mathrm{D} 1 \% 80 \% \mathrm{D} 1 \% 83 \% \mathrm{D} 1 \% 87 \% \mathrm{D} 0 \% \mathrm{BD} \% \mathrm{D} 0 \% \mathrm{~B} 8 \%$ D0\%BA.pdf (in Russian)

Chernyk, P. 2017. Geopolitical position of Ukraine in Central and Eastern Europe. Lviv .: Ivan Franko National University of Lviv: dis ... Cand. flight. Science: 23.00.04 (in Ukrainian).

Brzezinski, Z. 1999. American domination and its geostrategic imperatives. International Relations. Ivano-Frankivsk.: Lileya (in Ukrainian) .

Dugin, A.G. 1997. Fundamentals of geopolitics. Russia's geopolitical future. Moscow: Arktogeyatsentr (in Russian).
Galchinsky, A.S. 2002. Ukraine - at the crossroads of geopolitical interests. Kyiv: Znannya Ukrayny(in Ukrainian).

Karpenko, M. 2004. European vector in the development of geostrategy of Ukraine. Kharkiv: Scientific works. Issue 56, Vol. 147: 69-120 (in Ukrainian).

Klyuchko, D. 2005. Geostrategic dilemma of Ukraine: theoretical and methodological analysis and institutional solutions: Dis ... cand. political science. Kharkiv: V. N. Karazin Kharkov National University. URL: http://www.disslib.org/heostratehichna-dylemaukrayiny-teoretyko-metodolohichnyi-analiz-tainstytutsionalni2.html (in Ukrainian).

Madison, V., Shakhov, V. 2003. Modern Ukrainian geopolitics a textbook for universities. Kyiv: Lybid' (in Ukrainian).

Palamarchuk, M., Palamarchuk, O. 1994. Geopolitical position of Ukraine (essence and main features). Kherson: Ukrains'kyy heografichnyy zhurnal. 1 : 3-9 (in Ukrainian).

Vasylenko, S.D. 2000. Ukraine: Geopolitical dimensions in pan-European process. Odessa: ODMA. (in Ukrainian).

Yatsenko, B.P, Stafiychuk, V.I, Braychevsky, Y.U. 2007. Political geography and geopolitics. Kyiv: Lybid' (in Ukrainian).

\section{Марусик Юрій Васильович} науковий співробітник, Міжнародний інститут освіти, культури та зв' язків 3 діаспорою Національного університету «Львівська політехніка» вул. С. Бандери 32 Д, м. Львів, 79000, yuriy_m@outlook.com,

https://orcid.org/0000-0001-5524-0122

\section{ІНСТИТУЦІАЛІЗАЦІЯ АКТИВІЗМУ УКРАЇНСЬКИХ МІГРАНТІВ У КРАЇНАХ ЕВРОПЕЙСЬКОГО СОЮЗУ}

Розглянуто різні підходи до визначення та оиінки інституціалізаиії громадського активізму. Проаналізовано дані оригінальних досліджень, в яких автор із колегами проводили опитування громадсько активної української молоді у країнах ЄС (використано глибинне інтерв'ювання). Респондентами дослідження були українські молодіжні активісти, які діють у Німеччині, Франщії, Італії, Іспанії, Португалії, Польщі та Чехії. На основі цьього дослідження проаналізовано сучасний стан інститучіалізаиії украйнського активізму в різних краӥнах Євросоюзу.

3'ясовано, що робота об'єднань мігрантів є різноплановою та зазвичай базується на ентузіазмі чи зачікавленості активістів, а це сприяє гнучкості роботи, близькості до потреб та переконань відповідних громад, але не гарантуе високого рівня сталості діяльності. 